\title{
Bifidobakterium dan Kesehatan Saluran Cerna pada Anak
}

\author{
Reza Ranuh, ${ }^{1}$ Badriul Hegar ${ }^{2}$ \\ ${ }^{1}$ Departemen Ilmu Kesehatan Anak Fakultas Kedokteran Universitas Airlangga Rumah Sakit Dr. Sutomo, Surabaya \\ ${ }^{2}$ Departemen Ilmu Kesehatan Anak Fakultas Kedokteran Universitas Indonesia Rumah Sakit Dr. Cipto Mangunkusumo, Jakarta
}

\begin{abstract}
Kolonosisasi mikrobiota saluran cerna yang didominasi oleh mikrobiota sehat merupakan aspek penting dalam optimalisasi kesehatan anak. Komposisi mikrobiota saluran cerna selalu berubah pada setiap keadaan karena banyak faktor yang memengaruhinya. Bifidobacteria terdapat dalam Air Susu Ibu dan mendominasi saluran cerna bayi yang mendapat ASI eksklusif, seringkali dikaitkan dengan kesehatan bayi dan anak dikemudian hari. Bifidobacteria dikategorikan dalam dua kelompok, yaitu (1) spesies Bifidobacteria berasal dari manusia (buman residential bifidobacteria/HRB) dan (2) spesies Bifidobacteria yang secara alami berkoloni di hewan/ lingkungan (non-HRB). Bifidobacteria breve, B. longum subsp.infantis, dan B. bifidum adalah HRB yang terdapat pada bayi. Kolonisasi usus bayi ASI eksklusif didominasi oleh HRB saat berusia 2 minggu. Suplementasi HRB memberikan efek protektif NEC pada bayi dengan usia gestasi <34 minggu. Resolusi sakit perut bermakna terlihat pada irritable bowel syndrome yang mendapat suplementasi HRB, walaupun demikian belum cukup kuat bukti untuk menyatakan bahwa probiotik lebih efektif dalam mencegah kolik infantil. Sari Pediatri 2020;22(3):190-6
\end{abstract}

Kata kunci: human residential bifidobacteria,Bifidobacteria, air susu ibu, saluran cerna, bayi

\section{Bifidobacterium and Gastrointestinal Health in Children}

Reza Ranuh, ${ }^{1}$ Badriul Hegar ${ }^{2}$

Colonization of the gut microbiota which is dominated by healthy microbiota is an important aspect in optimizing children's health. The composition of the gut microbiota always changes in every situation because of many factors that influence it. Bifidobacteria are found in breast milk and dominate the gut of infants who are exclusively breastfed, often associated with the health of babies and children in the future. Bifidobacteria are categorized into two groups, (1) Bifidobacteria species derived from humans (human residential bifidobacteria / HRB) and (2) Bifidobacteria species that naturally colonize in animals / environment (non-HRB). Bifidobacteria breve, B. longum subsp.infantis, and B. bifidum are HRB found in infants. Gut colonization of exclusively breastfed infants was dominated by HRB at 2 weeks of age. HRB supplementation exerts a protective effect on NEC in infants <34 weeks' gestation. Significant abdominal pain resolution has been seen in irritable bowel syndrome receiving HRB supplementation, although there is not enough evidence to suggest that probiotics are more effective in preventing infantile colic. Sari Pediatri 2020;22(3):190-6

Keyword: human residential bifidobacteria, Bifidobacteria, breast milk, gut, infants

Alamat korespondensi: Badriul Hegar. Departemen Ilmu Kesehatan Anak Fakultas Kedokteran Universitas Indonesia Rumah Sakit Dr. Cipto Mangunkusumo, Jakarta. Email: bhegars@gmail.com 
S aluran cerna merupakan organ utama yang berfungsi mencerna dan menyerap zat nutrisi yang masuk ke dalam tubuh. Di dalam saluran cerna, hidup dan berkembang berbagai jenis mikrobiota. Mikrobiota saluran cerna yang memberikan manfaat bagi manusia dikenal sebagai mikrobota sehat (useful) dan kelompok mikrobiota yang memberikan kerugian bagi manusia dikenal sebagai mikrobiota patogen (harmful). Kolonosisasi mikrobiota saluran cerna yang didominasi oleh mikrobiota sehat merupakan salah satu aspek penting dalam optimalisasi kesehatan anak. ${ }^{1}$

Kolonisasi dan diversitas mikrobiota saluran cerna, terutama saat awal kehidupan memberikan dampak yang besar terhadap sistem imun sebagai mekanisme pertahanan dan tolerans, sistem digesti dan absorpsi menghasilkan proses metabolisme yang baik, dan sistem gut-brain axis untuk memberikan rasa nyaman. Komposisi mikrobiota saluran cerna selalu berubah pada setiap keadaan karena banyak faktor yang memengaruhinya, termasuk faktor genetik individu. Gangguan komposisi mikrobiota saluran cerna merupakan penyebab penyakit dan bukan sebaliknya. ${ }^{2,3}$

Bifidobacteria merupakan salah satu jenis mikrobiota yang banyak terdapat di dalam Air Susu Ibu (ASI) dan mendominasi saluran cerna bayi yang mendapat ASI eksklusif, seringkali dikaitkan dengan kesehatan bayi dan anak dikemudian hari. Suplementasi Bifidobacteria sebagai probiotik dengan pertimbangan bahwa Bifidobacteria terkandung di dalam ASI, memerlukan kajian komprihensif karena tidak semua data memperlihatkan hasil bermanfaat, meskipun tidak memberikan hasil yang buruk (adverse reaction). Spesifikasi galur dan uji klinis dengan metodologi yang baik menjadi prasyarat sebelum suplementasi tersebut diberikan kepada manusia.

\section{Kolononisasi mikrobiota saluran cerna bayi}

Proses kolonisasi mikrobiota saluran cerna berlangsung bertahap yang dimulai sejak pranatal. Saat ibu hamil dan menyusui terjadi translokasi mikrobiota dari ibu ke bayi. ${ }^{4}$ Translokasi mikrobiota merupakan kejadian fisiologi yang unik. Mikrobiota saluran cerna bayi yang lahir pervaginam dan mendapat ASI eksklusif, secara umum dianggap sebagai 'mikrobiota sehat'.

Sebuah analisis perkembangan mikrobiota saluran cerna memperlihatkan dominasi Bifidobacteria pada tinja bayi mendapat ASI eksklusif, sedangkan pada bayi yang mendapat susu formula standar, jumlah galur Bifidobacteria dan Lactobacillus hampir menyamai E.coli dan Bacteroides. ${ }^{5}$ Kajian lain juga memperlihatkan peningkatan kolonosisasi Bifidobacteria beberapa hari setelah lahir pada bayi yang mendapat ASI eksklusif dan stabil untuk beberapa waktu. ${ }^{6}$ Isolasi mikrobiota dari tinja bayi yang mendapat ASI eksklusif memperlihatkan Bifidobacteria sebagai mikrobiota yang dominan sejak lahir dan menurun sesuai bertambahnya usia. ${ }^{7}$ Kolononisasi beberapa spesies mikrobiota mengalami perubahan pada usia 6-12 bulan, tetapi Bifidobacteria terlihat relatif stabil pada saluran cerna bayi yang mendapat ASI eksklusif. ${ }^{8}$ Pengenalan makanan padat menyebabkan perubahan keragaman mikrobiota dan secara bertahap menyerupai profil mikrobiota orang dewasa pada usia 3 tahun. ${ }^{9}$ Kajian lain juga melihat keragaman mikrobiota saluran cerna pada 100 hari pertama kehidupan. ${ }^{10}$

Mikrobiota saluran cerna berkembang cepat pada 1 tahun pertama kehidupan. Saluran cerna bayi yang didominasi oleh mikrobiota sehat dan stabil menjadi salah satu kriteria sistem saluran cerna yang sehat. Beberapa faktor yang paling relevan dapat memengaruhi komposisi dan perkembangan mikrobiota saluran cerna bayi, di antaranya (1) usia gestasi (prematur vs cukup bulan), (2) tipe persalinan (bedah kaisar vs pervaginam), (3) pemberian nutrisi (ASI vs susu formula), (4) obat-obatan (PPI, antibiotik), (5) paparan lingkungan (NICU), dan (6) faktor genetik. ${ }^{11}$ Keberadaan mikrobiota yang sinergis (simbiosis) dapat menyebabkan toleransi imun, homeostasis saluran cerna, dan metabolisme yang baik. Sebaliknya, kondisi disbiosis mikrobiota dapat mengakibatkan keadaan patologi pada saluran cerna, misalnya mudah mengalami infeksi, necrotizing enterocolitis (NEC), inflamatory bowel diseases (IBD), begitu pula dengan gangguan saluran cerna fungsional (kolik, irritable bowel syndrome), atau alergi serta berbagai kondisi lainnya. ${ }^{12}$

Bayi yang lahir dengan bedah kaisar memiliki jumlah dan keberagaman bakteri yang rendah, ${ }^{13}$ dan mempunyai risiko lebih tinggi untuk mengalami alergi. ${ }^{14}$ Kolonisasi Bifidobacterium dan Bacteroides lebih rendah dengan kolonisasi Proteobacteria lebih tinggi pada bayi prematur dibanding kelompok bayi cukup bulan. ${ }^{15}$ Kolonisasi mikrobiota saluran cerna yang seimbang pada awal kehidupan akan memengaruhi perkembangan sistem pertahanan tubuh bayi. Sistem pertahanan tubuh yang terlatih sejak awal kehidupan 
dapat mengurangi reaksi berlebihan terhadap zat asing, baik dalam bentuk mikrooragnisme maupun bahan makanan. Keberadaan mikrobiota sehat yang cukup akan menghambat proses inflamasi dan stimulasi sistem imun berlebihan. ${ }^{16}$

\section{Mikrobiota saluran cerna dan ASI}

Di luar komponen nutrisi, ASI mengandung senyawa penting lainnya, antara lain, oligosakarida, sitokin, imunoglobulin, mikroba, dan protein, yang secara langsung memengaruhi perkembangan kolonisasi mikrobiota saluran cerna. Kadar sekretori IgA (SIgA) yang tinggi di dalam ASI merupakan mekanisme pertahanan tubuh bayi di lini pertama. Sekretori IgA ASI akan masuk ke dalam saluran cerna dan ikut mengontrol mikrobiota saluran cerna bayi melalui kemampuannya menghambat perlekatan mikrobiota patogen pada reseptor epitel saluran cerna sekaligus mengikat mikrobiota komensal. ${ }^{17,18}$ Jenis galur mikrobiota dan hasil digesti makanan berpengaruh terhadap pematangan GALT (Gut Associated lymphoid Tissue), yaitu jaringan limfoid yang membangun kurang lebih $40 \%$ keseluruhan jaringan saluran cerna, berfungsi memproduksi SIgA saluran cerna. ${ }^{19}$ Dengan demikian, terlihat keterkaitan yang erat antara SIgA ASI, mikrobiota saluran cerna bayi, GALT, dan SIgA saluran cerna bayi.

Human milk oligosacharides (HMO) yang merupakan komponen nutrisi terbanyak ketiga setelah laktosa dan lemak di dalam ASI, diketahui sebagai faktor selektif untuk pertumbuhan Bifidobacteria pada bayi yang mendapat ASI. Human milk oligosacharides akan difermentasi oleh Bifidobacteria di dalam usus besar menjadi energi dan SCFA. Lingkungan asam sebagai hasil fermentasi dan substansi aktif bakteriosin yang dihasilkan oleh Bifidobacteria menjadikan suasana kompatibel untuk pertumbuhan dan aktivitas mikrobiota sehat. ${ }^{20}$ Lingkungan ini dapat menghambat pertumbuhan dan perlekatan mikrobiota patogen pada permukaan sel epitel, sebagai molekul ko-agregasi yang memblokir penyebaran mikrobiota patogen, dan sekaligus sebagai sinyal terhadap sistem imun saluran cerna melalui produksi berbagai modulat sistem imun. Dengan demikian, saluran cerna yang didominasi oleh mikrobiota sehat memiliki barier yang lebih baik. ${ }^{21}$

'Growth factors' di dalam ASI dapat meningkatkan kolonisasi 'mikrobiota sehat' yang menghambat invasi mikrobiota patogen ke dalam saluran cerna bayi.
Mukosa saluran cerna bayi yang masih terbuka ('tight junction') memudahkan komponen-komponen yang terdapat dalam ASI masuk ke dalam saluran cerna dan aliran darah bayi. Laktoferin mempunyai efek bakterisid kuat sehingga dapat membatasi perlekatan bakteri patogen pada sel epitel. ${ }^{22}$ Komponen mikrobiota saluran cerna ibu dikirim ke payudara melalui sel mononukleus. Sel dalam ASI mengandung banyak petanda DNA bakteri, seperti yang ditemukan pada sel mononukleus darah perifer ibu. Pada saat menyusui terjadi transfer Bifidobacteria dan Lactobacillus yang berada di dalam ASI ke dalam saluran cerna bayi. ${ }^{23}$

\section{Probiotik}

Probiotik adalah mikrobiota hidup dalam jumlah tertentu yang diberikan kepada manusia, tetap hidup di dalam saluran cerna, dan memberikan dampak fisiologi yang memberi manfaat bagi kesehatan. Probiotik harus mendukung sistem pencernaan, sistem imunitas, maupun kesehatan secara keseluruhan dengan memicu keseimbangan mikrobiota saluran cerna.

Beberapa galur mikrobiota telah berhasil dikembangkan sebagai probiotik untuk mengembalikan keseimbangan mikrobiota saluran cerna bayi yang tidak mendapat ASI akibat berbagai faktor risiko. Galur Bifibocateria sebagai probiotik, meski tidak sebanyak galur Lactobacillus, telah cukup banyak diteliti oleh berbagai ahli terkait kesehatan saluran cerna. Secara logika, pemberian galur Bifidobactria tertentu akan mendominasi saluran cerna dan memberikan manfaat untuk kesehatan bayi, mengingat Bifiboabcetria adalah mikrobiota dominan di dalam ASI. Walaupun demikian, hal tersebut tidak akan mengganti banyak hal lain yang terdapat di dalam ASI yang tidak dapat disuplemen di dalam susu formula, seperti imunoglobulin A dan faktor imunologis lainnya.

Pengaruh suplementasi probiotik terhadap infeksi dan gangguan fungsional saluran cerna telah banyak dikaji, tetapi tidak semua memberikan hasil yang konklusif, bergantung dengan jenis mikrobiota dan kondisi penjamu. Kajian terhadap efektivitas dan keamanan probiotik pada bayi prematur juga masih terbatas dengan hasil tidak konsisten. Pemikiran memberikan paparan galur mikrobiota tertentu sejak dini dapat menyebabkan kolonisasi mikrobiota bertahan lebih lama hingga usia anak, remaja, atau dewasa, juga masih memerlukan dukungan penelitian yang lebih kuat. 


\section{Bifidobacteria}

Galur Bifidobacteria pada awalnya diduga hanya didapatkan pada bayi, tetapi pada kajian-kajian berikutnya, galur Bifidobacteria juga dijumpai pada usia dewasa. Bifidobacteria berbebtuk 'rod-shaped' dan 'Y-shaped' memiliki lebih dari 50 spesies dan 10 subspesies, berkolonisasi di dalam saluran cerna dalam jumlah yang sangat besar, sekitar 10 milyar/gram, dapat ditemukan dalam usus besar (kolon) manusia maupun hewan. Salah satu yang membedakan dengan Lactobacillus adalah hasil fermentasinya, yaitu lebih banyak mengandung asam asetat dibanding asam laktat. Dengan demikian, hasil fermentasi tersebut dapat menghambat pertumbuhan mikrobiota patogen, menekan respon inflamasi, dan meningkatkan fungsi barier saluran cerna. ${ }^{24}$

Secara umum, Bifidobacteria dikategorikan ke dalam dua kelompok utama, yaitu (1) spesies Bifidobacteria yang berasal dari manusia yang dikenal sebagai human residential bifidobacteria (HRB) dan (2) spesies Bifidobacteria yang secara alami berkoloni di hewan atau lingkungan (non-HRB). Spesies Bifidobacteria HRB yang terdapat pada bayi adalah $B$. breve, B. longum subsp. infantis, $B$. bifidum, sedangkan yang terdapat pada orang dewasa mencakup $B$. adolescentis, B. pseudocatenulatum, B. catenulatum. Bifidobacteria longum subs. longum tidak hanya terdapat pada bayi, tetapi juga pada orang dewasa. Bifidobacteria yang terdapat di hewan atau lingkungan adalah $B$. animalis subsp animalis, $B$. animalis subs lactis, B. thermophillum, dan B. pseudolongum. ${ }^{25}$

Evolusi beberapa galur Bifidobacteria menjadi salah satu tantangan menarik untuk lebih dipahami. Bifidobacteria infantis yang lebih mudah memetabolisme oligosakarida banyak ditemukan pada bayi, sedangkan Bifidobacterium longum yang lebih mudah memfermentasi karbohidrat kompleks sering ditemukan pada orang dewasa. ${ }^{27}$ Kajian yang dilakukan oleh Tannock $\mathrm{dkk}^{26}$ memperlihatkan kolonisasi mikrobiota saluran cerna bayi yang mendapat ASI eksklusif didominasi oleh B. longum B.breve, dan B. Bifidum (HRB), sedangkan B. pseudocatenulatum, B. adolescentis, dan $B$. catenulatum ditemukan dalam jumlah kecil, bahkan B. animalis (Non HRB) tidak terdeteksi. Sebuah kajian invitro pada 37 galur Bifidobacteria (10 spesies dan 6 subspesialis) memperlihatkan pertumbuhan yang baik dari semua jenis $B$. breve, $B$. infantis, B. bifidum, dan $B$. longum setelah diinkubasi pada ASI, sedangkan galur Bifidobacteria non-HRB terlihat tidak kompatibel sehingga mati saat inkubasi. ${ }^{27}$
Asam folat merupakan kofaktor penting pada berbagai reaksi biologis esensial. Kajian invitro yang dilakukan oleh Sugara $\mathrm{dkk}^{28}$ menyimpulkan bahwa galur Bifidobacteria (HRB) memproduksi asam folat dengan didapatkannya kadar asam folat yang tinggi pada medium yang mengandung galur Bifidobacteria (HRB) dan hal ini tidak terlihat pada galur Bifidobacteria lainnya (non-HRB).

Odamaki $\mathrm{dkk}^{29}$ mengkaji secara invitro kemampuan galur Bifidobacteria dalam memanfaatkan HMO pada medium yang mengandung komponen LNT dan LNB sebagai sumber karbohidrat. Terdapat pertumbuhan beberapa galur Bifodobacteria (HRB), sedangkan galur lainnya tidak terlihat atau minimal sekali. Galur Bifidobacteria (HRB) memiliki elemen genetik dan enzim yang terlibat dalam metabolisme glukan, seperti HMO, musin, maupun karbohidrat yang berasal dari makanan. Sebaliknya, galur Bifidobcateria non-HRB kurang mampu melakukan metabolisme karbohidrat yang beragam pada manusia. ${ }^{30}$ Thongaram $\mathrm{dkk}^{31}$ memperlihatkan HMO sebagai faktor selektif untuk pertumbuhan beberapa galur Bifidobacteria dengan didapatkannya fermentasi beberapa komponen HMO, seperti 3'-sialyllactose, 6'-sialyllactose, 2'-fucosyllactose, 3'-fucosyl-lactose oleh B. longum ssp. infantis ATCC 15697 dan $B$. infantis $M-63$, serta lacto- $N$-neotetraose oleh B. breve ATCC 15700, B. infantis, dan L. acidophilus NCFM. Bahkan hampir semua 2'-fucosyllactose (95\%) difermentasi oleh $B$. infantis $M-63$.

Beberapa galur Bifidobacteria (HRB) mampu memfermentasi mucin dengan terlihatnya pertumbuhan galur B. bifidum, B. breve, dan B. longum dalam media yang mengandung mucin. Galur tersebut memanfaatkan mucin sebagai sumber karbon untuk berkolonisasi lebih baik dan bertahan hidup lebih lama. Sebaliknya, galur $B$. animalis dan $B$. pseudocatenulatum hanya mempunyai kemampuan pertumbuhan minimal. ${ }^{32}$

\section{Bifidobacteria sebagai probiotik untuk kesehatan saluran cerna}

Berbagai kajian mengenai peran Bifidobacteria sebagai probiotik terhadap kesehatan anak telah cukup banyak dilakukan, termasuk yang membandingkan Bifidobacteria (HRB) dan Bifidobacteria non-HRB. Kolononisasi sementara (transient) terjadi pada 11 bayi berumur 0-8 minggu yang disuplementasi oleh B. longum BB-536, B. breve BB-576, dan Lactobacillus 
acidophilus LAC-343 selama 5 hari. Kolononisasi masih terlihat pada $82 \%$ spesimen tinja pada hari ke6 , dan berkurang menjadi $22 \%$ pada hari ke-20. Pada suplementasi tersebut tidak ditemukan efek samping pada semua bayi. ${ }^{33}$

Jenis dan cara pemberian mikrobiota dapat memengaruhi luaran. Di Finlandia, Grzeskowiak dkk ${ }^{34}$ memberikan probiotik kepada ibu hamil $(\mathrm{n}=79)$ selama 2 bulan sebelum melahirkan dan dilanjutkan selama 2 bulan setelah melahirkan. Sementara di Jerman, Gronlund $\mathrm{dkk}^{34}$ mulai memberikan probiotik saat bayi berusia 1 bulan $(\mathrm{n}=81)$ dan dilanjutkan selama 4 bulan. Kolononisasi mikrobiota pada saluran cerna bayi yang mendapat ASI sampai berusia 6 bulan cenderung dihuni lebih banyak oleh Bifidobacteria pada kelompok bayi di Finlandia (22 bayi) dibanding di Jerman ( 8 bayi) $(p=0,097)$ dan lebih beragam pada kelompok bayi di Jerman.

Suplementasi B. breve kepada bayi berat lahir rendah $( \pm 1489$ gram $)$ segera setelah lahir memperlihatkan kolonisasi yang didominasi oleh Bifidobacteria saat berusia 2 minggu, sedangkan bila suplementasi diberikan saat 24 jam setelah lahir, pertumbuhan Bifidobacteria baru terlihat pada usia 4 minggu. Kolonisasi Bifidobacteria tidak terdeteksi pada $80 \%$ bayi yang tidak mendapat suplementasi sampai berusia 7 minggu. Sebaliknya, kolonisasi Enterobacteriaceae terdeteksi lebih rendah secara bermakna pada kelompok bayi yang mendapat suplmentasi sejak lahir. ${ }^{35}$

Beberapa galur yang beraktivitas secara sinergis menghasilkan kolonisasi yang lebih cepat dibanding pemberian satu galur. Suplementasi kombinasi $B$. breve $M-16, B$ longum $B B$ 536, dan B. breve $M-63$ pada bayi barat lahir rendah (BBLR) menghasilkan kolonisasi yang jauh lebih tinggi pada minggu pertama dibanding dengan pemberian hanya $B$. breve $M-16$, meskipun kolonisasi yang sama terlihat pada minggu berikutnya hingga minggu kedelapan. Pada kombinasi tersebut terlihat B. breve $M-16$ Vlebih dominan dibanding galur lainnya. Kolonisasi Clostridium dan Enterobacteriaceae juga terlihat lebih rendah pada bayi yang mendapat kombinasi mikrobiota. ${ }^{36}$

Suplementasi Bifidobacteria pada bayi cukup bulan dan bayi kurang bulan (gestasi <29 minggu) memperlihatkan perbedaan bermakna terhadap kejadian NEC (> stadium 2) dan kematian secara keseluruan (12\% VS 21\%, P=0,04). ${ }^{37}$ Suplementasi B. breve $M-16$ V pada 22 bayi Low Birth Weight/LBW $(<2500 \mathrm{~g})$, 22 bayi very $L B W(<1500 \mathrm{~g})$, dan 22 bayi extremely $L B W$
$(<1000 \mathrm{~g})$ meningkatkan kadar asam asetat dan SCFA total, serta mengurangi produksi asam butirat sehingga membantu melindungi bayi BBLR dari penyakit saluran cerna seperti enterokolitis nekrotikans. ${ }^{38}$

'Systemic review' mengenai efikasi $B$. breve, $B$. lactis, dan B. bifidum terhadap pencegahan NEC pada bayi dengan berat lahir sangat rendah, menyimpulkan bahwa $B$. breve dan B. lactis memberikan efek protektif terhadap kejadian NEC pada bayi dengan usia gestasi < 34 minggu dengan RR 0.43 (95\% CI: 0.21-0.87, $\mathrm{P}=0.019)$ dan RR 0.11 (95\% CI:0.03-0.47, $\mathrm{P}<0.001$ ). Efek $B$. breve tidak terlihat pada bayi dengan usia gestasi $<28$ minggu. Belum cukup data untuk menyimpulkan B. bifidum. ${ }^{39}$

Suplementasi B. longum BB536 pada 264 bayi sehat memberikan efek positif pada komposisi mikrobiota saluran cerna dan respon imun di awal kehidupan. Jumlah Bifidobacteria lebih tinggi secara bermakna dibanding Enterobacteriaceae pada minggu kedua dan keempat. Respon imun Th1 terlihat lebih baik pada minggu ketujuh, meski tidak terlihat perbedaan respon antibodi terhadap vaksinasi pada minggu kesebelas. ${ }^{40}$

Efektivitas Bifidobacteria juga dinilai pada gangguan saluran cerna fungsional. Sebuah randomized controlled trial terhadap 55 anak berusia 4-12 tahun dengan konstipasi fungsional memperlihatkan bahwa kelompok anak yang mendapatkan terapi Polyethylene glycol (PEG) dan kelompok anak yang mendapat PEG + probiotik (B. breve $M-16$ V, B. infantis $M-63, B /$ longum BB536) sama efektifnya dan aman dalam perbaikan klinis setelah pemberian selama 1 bulan ( $88 \%$ VS $81,8 \% ; \mathrm{P}=0,24)$ ) dan remisi klinis $(52 \%$ VS $64 \%$; $\mathrm{P}=0,28) .{ }^{41}$

Suplementasi $B$. breve $M-16 V$, B. infantis $M-63$, dan B. longum BB536 pada anak dengan irritable bowel syndrome (IBS) memperlihatkan perbedaan yang bermakna antara kelompok anak yang mendapat Bifidobacteria dan plasebo dalam resolusi total sakit perut $(\mathrm{p}=0,006)$, berkurangnya frekuensi sakit perut $(\mathrm{p}=0,02)$, dan perbaikan kualitas hidup ( $48 \%$ VS $17 \%, \mathrm{p}=0,001) .{ }^{42}$ Systemic review mengenai pemberian probiotik pada irritable bowel syndrome, memperlihatkan 7 dari 11 penelitian melaporkan perbaikan gejala sakit perut secara bermakna dibanding plasebo, sedangkan 4 penelitian lainnya tidak terlihat perubahan gejala setelah mendapat probiotik. Pemberian multistrain dalam waktu tertentu berpotensi memperbaiki gejala klinis. ${ }^{43}$ Data yang berbeda terlihat pada kajian yang dilakukan oleh Nafarin $\mathrm{dkk}^{44}$ (2019) yang tidak mendapatkan perbedaan bermakna jumlah spesies Bifidobacteria dan 
Enterobacteriaceae pada remaja sehat dan remaja dengan gangguan saluran cerna fungsional $(\mathrm{p}=0,49$ dan $\mathrm{p}=0,94)$.

Bayi dengan kolik infantil mempunyai keberagaman dan stabilitas mikrobiota saluran cerna yang rendah pada minggu pertama kehidupannya. ${ }^{45}$ Manfaat suplementasi mikrobiota tertentu untuk mengurangi gejala kolik masih belum jelas, meski beberapa galur Lactobacillus dan Bifidobacterium dilaporkan dapat mengurangi gejala kolik. Cochrane database of systematic reviews terhadap suplementasi probiotik untuk mencegah kolik infantil menyimpulkan bahwa meski frekuensi tangisan terkesan berkurang dengan pemberian probiotik dibanding plasebo, tetapi belum cukup bukti yang kuat bahwa probiotik lebih efektif dibanding placebo untuk mencegah kolik infantil. ${ }^{46}$ Cochrane database of systematic reviews terhadap penggunaan probiotik, termasuk Bifidobacteris spp untuk mencegah antibiotic associated diarrhea (AAD) memperlihatkan angka kejadian $\mathrm{AAD}$ jauh lebih rendah pada kelompok anak yang mendapat probiotik dibanding kelompok kontrol (8\% VS 1923\%). Tidak semua probiotik memperlihatkan efek untuk pencegahan AAD. ${ }^{47}$

\section{Kesimpulan}

Kolonisasi saluran cerna bayi yang didominasi oleh mikrobiota sehat perlu selalu diupayakan, agar dapat berkontribusi dalam proses metabolisme (digesti dan absorpsi), fungsi kekebalan (pertahanan dan toleransi), serta komunikasi gut-brain yang baik untuk menciptakan kesehatan dan kualitas hidup yang optimal.

\section{Daftar pustaka}

1. Milani C, Duranti S, Bottacini F, Casey E, Turroni F, Mahony J, dkk. The first microbial colonizers of the human gut: composition, activities, and health implications of the infant gut microbiota. Microbiol Mol Biol Rev 2017;81:3-13.

2. Vandenplas Y, Ludwig T, Szajewska H. Gut health in early life: implications and management of gastrointestinal disorders. London: John Wiley and Sons; 2015.

3. Carabottia M, Sciroccoa A, Masellib MA, Severia C. The gutbrain axis: interactions between enteric microbiota, central and enteric nervous systems. Ann Gastroenterol 2015;28:203-9.

4. Perez PF, Dore J, Leclerc M, dkk. Bacterial imprinting of neonatal immune system: lesson from maternal cells? Pediatrics 2007;119:e724-32.

5. Harmsen HJ, Wildeboer-Veloo AC, Raangs GC, dkk. Analysis of intestinal flora development in breast-fed and formula-fed infants by using molecular identification and detection methods. J Pediatr Gastroenterol Nutr 2000;30:61-7.

6. Nagpal R, Kurakawa T, Tsuji H, dkk. Evolution of gut Bifidobacterium population in healthy Japanese infants over the first three years of life: a quantitative assessment. Sci Rep 2017;7:10097-108.

7. Matamoros S, Gras-Leguen C, Le Vacon F, Potel G, de La Cochetiere MF. Development of intestinal microbiota in infants and its impact on health. Trends Microbiol 2013;21:167-73

8. Endo A, Partty A, Kalliomaki K, Isolauri E, Salminen S. Longterm monitoring of the human intestinal microbiota from the 2nd week to 13 years of age. Anaerobe 2014;6: 149-56

9. Derrien M, Alvarez AS, de Vos WM. The gut microbiota in the first decade of life. Trends Microbiol 2019;27:997-1010. doi.org/10.1016/ j.tim.2019.08.001.

10. Stewart CJ, Embleton ND, Clements E, dkk. Cesarean or vaginal birth does not impact the longitudinal development of the gut microbiome in a cohort of exclusively preterm infants. Front Microbiol 2017;8:1-9.

11. Tamburini S, Shen N, Wu HC, Clemente JC. The microbiome in early life: implications for health outcomes. Nat Med 2016;22:713-22.

12. Tanaka M, Nakayama J. Development of the gut microbiota in infancy and its impact on health in later life. Allergol Int 2017;66:515-22

13. Azad MB, Konya T, Maughan H, dkk . Gut microbiota of healthy Canadian infants: profiles by mode of delivery and infant diet at 4 months. CMAJ 2013;185:385-94.

14. Renz-Polster H, David MR, Buist AS, dkk . Caesarean section delivery and the risk of allergic disorders in childhood Clin Exp Allergy 2005;35:1466-72.

15. Stewart CJ, Embleton ND, Clements E, dkk . Cesarean or vaginal birth does not impact the longitudinal development of the gut microbiome in a cohort of exclusively preterm infants. Front Microbiol 2017;8:1-9.

16. Koletzko B, Aggett PJ, Bindels JG, Bung P, Ferré P. Growth, development and differentiation: a functional food science approach. Br J Nutr 1998;80 Suppl 1:S5-45.

17. Kohler H. Antibacterialcharacteristic in the feces of breast-fed and formula-fed infants during the first year of life. J Pediatr Gastroenterol Nutr 2001;34:188-93.

18. Mantis NJ, Rol N, Corth B. Complex roles in immunity and mucosal homeostasis in the gut. Review 2011;4:603-9.

19. Walter J, Ley RE. The human gut microbiome: ecology and recent evolutionary changes. Annu Rev Microbiol 2011;65:411-29. 
20. Gänzle MG, Follador R. Metabolism of Oligosaccharides and Starch in Lactobacilli: A Review. Front Microbiol 2012;3:340.

21. Cheikhyoussef A, Pogori, N, Zhang. Antimicrobial proteinaceous compounds obtained from bifidobacteria: from production to their application. Int J Food Microbiol 2008;125:215-22.

22. Andersson Y, Lindquist S, Lagerqvist C, Hernell O. Lactoferrin is responsible for the fungistatic effect of human milk. Early Hum Dev 2000;59:95-105.

23. Perez PF, Dore J, Leclerc M, Levenez F, Benyacoub J, Serrant P.. Bacterial imprinting of neonatal immune system : lesson from maternal cells? Pediatrics 2007;119:e724-32.

24. Parte AC. LPSN - list of prokaryotic names with standing in nomenclature. Nucleic Acids Res 2014;42:D613-6.

25. Wong CB, Sugahara H, Odamaki T, Xiao JZ. Different physiological properties of human-residential and non-humanresidential bifidobacteria in human health. Benef Microbes 2018, 9:111-22.

26. Tannock GW, Lawley B, Munro K, dkk. Comparison of the compositions of the stool microbiotas of infants fed goat milk formula, cow milk-based formula, or breast milk. App Environ Microbiol 2013;79:3040-8.

27. Minami J, Odamaki T, Hashikura N, Abe F, Xiao JZ. Lysozyme in breast milk is a selection factor for bifidobacterial colonisation in the infant intestine Benef Microbes 2016;7:53-60.

28. Sugara H, Odamaki T, Hashikura Ndkk . Differences in folate production by bifidobacteria of different origins. Biosci Microbiota Food Health 2015;34 :87-93.

29. Odamaki T, Horigome A, Sugahara H, dkk. Comparative genomics revealed genetic diversity and species/strain-level differences in carbohydrate metabolism of three probiotic Bifidobacterial species. Int J Genomics 2015;2015:1-12.

30. O'Callaghan and van Sindaren. Bifidobacteria and their role as members of human gut microbiota : A review. Front Microbiol 2016;7:1-23.

31. Thongaram T, Hoeflinger JL, Chow J, Miller MJ. Human milk oligosaccharide consumption by probiotic and human-associated bifidobacteria and lactobacilli. J Dairy Sci 2017;100:7825-33.

32. Abe F, Muto M, Yaeshima T, dkk. Safety evaluation of probiotic Bifidobacteria by analysis of mucin degradation activity and translocation ability. Anaerobe 2010;16:131-6.

33. Bennet R, Nord CE, Zetterstrom R. Transient colonization of the gut of newborn infants by orally administered bifidobacteria and lactobacilli. Acta Paediatr 1992;81:784-7.

34. Grzeskowiak L, Grönlund MM, Beckmann C, Salminen S, von Berg A, Isolauri E. The impact of perinatal probiotic intervention on gut microbiota: Double-blind placebo-controlled trials in Finland and Germany. Anaerobe 2012;18:7-13

35. Li Y, Shimizu T, Hosaka A, Kaneka N, Ohtsuka Y, Yamas- hiro Y. Effects of bifidobacterium breve supplementation on intestinal flora of low birth weight infants. Pediatrics Int 2004;46:509-15.

36. Ishizeki S, Sugita M, Takata M, Yaeshima T. Effect of administration of bifidobacteria on intestinal microbiota in low-birth-weight infants and transition of administered bifidobacteria: A comparison between one-species and threespecies administration. Anaerobe 2013;23:38-44.

37. Jape GA, Minaee N, Nathan E, Simmer K, Patole S. Outcome in preterm small versus appropriate for gestation infants after Bifidobacterium breve M-16 supplementation. Fetal Neonatal Med 2020;33:2209-15.

38. Chongxin Wang, Hiromichi Shoji, Hiroaki Sato, dkk. Effects of oral administration of Bifidobacterium breve on fecal lactic acid and short-chain fatty acids in low birth weight infants. J Pediatr Gastroenterol Nutr 2007;44: 252-7.

39. Hagen PC, Skelley JW. Efficacy of Bifidobacterium species in prevention of necrotizing enterocolitis in very-low birth weight infants. A systematic review. J Pediatr Pharmacol Ther 2019;24:10-5.

40. Wu BB, Yang Y, Xu X, Wang WP. Effects of Bifidobacterium supplementation on intestinal microbiota composition and the immune response in healthy infants. World J Pediatr 2016;12:177-82.

41. Russo M, Giugliano FP, Quitadamo P, dkk. Efficacy of a mixture of probiotic agents as complementary therapy for chronic functional constipation in childhood. Ital J Pediatr 2017;43:1-7.

42. Gianneti E, Maglione M, Alessandrella, A, dkk. A mixture of 3 Bifidobacteria decreases abdominal pain and improves the quality of life in children with irritable bowel syndrome: a multicenter, randomized, double-blind, placebo-controlled, crossover trial. Clin Gastroenterol 2017;51:e5-10.

43. Dale HF, Rasmussen SH, Asiller OO, Lied GA. Probiotics in Irritable Bowel Syndrome: An Up-to-Date Systematic Review. Nutrients 2019;11:2048.

44. Nafarin AR, Hegar B, Sjakti HA, Vandneplas Y. Gut microbiome pattern in adolescents with functional gastrointestinal disease. J Pediatr Adolesc Med 2019;6:12-5.

45. de Weerth C, Fuentes S, Puylaert P, de Vos WM. Intestinal microbiota of infants with colic: development and specific signatures. Pediatrics 2013;131:550-8.

46. Ong TG, Gordon M, Banks SSC, Thomas MR, Akobeng AK. Probiotics to prevent infantile colic. Cochrane Database Syst Rev 2019: CD012473. doi: 10.1002/ 14651858.cd012473.pub2.

47. Guo Q, Goldenberg JZ, Humphrey C, El Dib R, Johnston BC. Probiotics for the prevention of pediatric antiviotic-associated diarrhea. Cochrane Database Syst Rev 2019: CD004827. doi: 10.1002/14651858.CD004827.pub5. 